\title{
REKONSTRUKSI DAN PENGEMBANGAN MATERI AL-ISLAM DI LEMBAGA PENDIDIKAN MUHAMMADIYAH
}

\author{
Yazida Ichsan \\ Universitas Ahmad Dahlan \\ yazida.ichsan@pai.uad.ac.id
}

\section{Abstrak}

Perkembangan Istinbat ahkam di dalam Muhammadiyah dengan berbagai pendekatan dan perspektif secara langsung akan berdampak kepada pola pikir maupun sistem pendidikan di Muhammadiyah. Perkembangan inovasi materi pendidikan masa $\mathrm{KH}$. Ahmad Dahlan yang trasendent, terbuka dan toleran perlu direnungi kembali sehingga, saat ini model-model pemikiran tidak terjebak pada keputusan yang ekslusif. Sebagai harakah da'wah yang salah satunya menggunakan media pendidikan sebagai jalan, perkembangan yang sedemikian rupa, perlu adanya perspektif baru yang menggabungkan nalar purifikasi maupun dinamisasi sebagai wadah bagi kemajuan pendidikan ibadah. Artikel ini berusaha untuk memberikan gambaran dan memberikan sebuah alternatif perlunya pengembangan konten materi pendidikan ibadah sebagai upaya menjawab tantangan perkembangan zaman, dengan berbagai hiruk-pikuk permasalahan yang terjadi.pada saat ini. Perkembangan pendekatan di Majelis Tarjih pun menjadi tolak ukur bahwa pendidikan harus secara aktif dan dinamis menjawab sebuah tantangan radikalisme, mistisisme dan liberalisme sehingga terwujudnya organisasi moderat yang melahirkan siswa yang secara intelektual memiliki pengetahuan yang holistik, terinternalisasi dan mengkristalnya nilai-nilai keagamaan dengan mampu menanggapi tantangan kemajuan.

\section{Abstract}

The development of Istinbat ahkam in Muhammadiyah with various approaches and perspectives will directly affect the mindset and the education system in Muhammadiyah. The development of innovative educational materials during the KH. Ahmad Dahlan who is transcendent, open and tolerant needs to be reconsidered so that, at present the models of thought are not trapped in exclusive decisions. As a religious missionary one of which uses educational media as a way, such a development, there needs to be a new perspective that combines purification and dynamism as a forum for the advancement of religious education. This article seeks to 
Yazida Ichsan : Rekonstruksi Dan Pengembangan Materi Al-Islam di Lembaga Pendidikan Muhammadiyah

provide an illustration and provide an alternative need for the development of religious education material content in an effort to answer the challenges of the times, with a variety of the hustle and bustle of the problems that occur at this time. The development of the approach in the Tarjih Assembly also became a benchmark that education must actively and dynamically answer a challenge of radicalism, mysticism and liberalism so that the realization of a moderate organization that gave birth to students who intellectually possess holistic, internalized and crystallized religious values by being able to respond to the challenges progress.

\section{A. Pendahuluan}

Islam dalam pemahaman Muhammadiyah bisa dibedakan dalam empat tahap historis. Pertama, Islam masa K.H.Ahmad Dahlan tampak lebih kultural, terbuka dan toleran bukan hanya pada tradisi lokal yang diwakili oleh tradisi keraton, tetapi juga pada pengalaman sosial masyarakat barat yang tercermin dalam komunitas warga penjajah dan penganut Kristen dan Khatolik. 80 Kedua, formalisasi syari'ah masa dominasi ahli syariah yang terlembaga dalam tarjih yang berfungsi (tarjih) sebagai lembaga fatwa syari'ah atau sebagai era ideologi. Ketiga, era spiritualisasi syari'ah pada masa kepemimpinan generasi baru berpendidikan tinggi modern. Keempat, era reideologisasi fatwa tarjih. ${ }^{81}$

Disisi lain M.Amin Abdullah menggambarkan bahwa banyak kalangan merasakan bahwa Muhammadiyah mengalami fenomena rigiditas yang tidak lagi memberikan kenyamanan secara ontologis, epistemologis maupun aksiologis dengan berfikir secara filosofis dan terjebak pada sakralitas pemikiran

80 Lihat Api Sejarah: KH.Ahmad Dahlan sangat paham dan sadar bahwa usaha yang dilakukannya pasti akan terbentur pada tembok tradisi Kasoenanan Soerakarta dan Kesoeltanan Yogyakarta, kondisi sosial ekonomi masyarakat akar rumput menyebabkan kemiskinan terhadap ajaran agama sehingga timbulnya ajaran tahayul, kemusyrikan, khurofat dan bid'ah.

81 Abdul Munir Mulkhan, Ajaran dan Pemikiran K.H. Ahmad Dahlan, (Yogyakarta : Galangpress. 2013), hlm 58 
(taqdisul afkar) yang sakral, eksklusif, ideologis dan teralienasi dari dinamika sosial. ${ }^{82}$

Kedua hal tersebut nampaknya perlu adanya kontemplasi yang mendalam terkait dengan kondisi "masyarakat" Muhammadiyah dan lembaga pendidikan Muhammadiyah saat ini sehingga perlu adanya kesadaran bahwa pendidikan Agama yang saat ini diajarkan perlu dikaji ulang dan dikonstruksi pada tataran ajaran yang non komulatif dan mampu menjawab tantangan zaman yang semakin kompleks dengan beberapa permasalahan sebagai dampak kemajuan.

Pesatnya perkembangan lembaga pendidikan yang dimiliki Muhammadiyah seharusnya berbading dengan kemajuan, pemikiran, kebudayaan dan peradaban yang dihasilkan oleh lembaga pendidikan. Disisi lain, karakteristik, corak, maupun watak yang lebih modern, dengan perspektif bahwa pintu ijtihad senantiasa terbuka, memberikan angin segar bahwa upaya dekodifikasi dan demistifikasi83 terhadap ajaran Islam menjadi corak positif terhadap kemajuan pendidikan al-Islam dan kemuhammadiyahan di lingkungan Muhammadiyah. Dengan Prinsip al-muraa'ah (koservasi), attahditsi (inovasi), al-Ibda'i (kreasi) ${ }^{84}$ menjadikan sekolah Muhammadiyah mampu mengkontektualisasikan dan mengaktualisasikan ajaran islam yang berkemajuan dan beradab.

82 M.Toyibi dkk. Muhammadiyah dan Budaya Lokal : Dialektika Muhammadiyah dan Seni Lokal (Surakarta: UMS press. 2003), hlm.15

83 Dekodifikasi merupakan penjabaran Al-Quran dan Sunnah ke dalam ilmu-ilmu agama dan demistifikasi sebuah pemahaman dan mengamalan yang menitikberatkan kepada hal-hal mistik. Dalam hal ini Kuntowijoyo mengklasifikasikan bahwa umat islam terjebak pada lima macam mistik: Mistik metafisik, sosial, etis, penalaran dan kenyataan. Kuntowijoyo. Islam Sebagai Ilmu (Yogyakarta: Tiara Wacana, 2006), hlm. 6-9

84 Syarif Hidayatullah, Muhammadiyah dan pluralitas agama di Indonesia, (Yogyakarta : Pustaka Pelajar 2004), hlm 56 
Yazida Ichsan : Rekonstruksi Dan Pengembangan Materi Al-Islam di Lembaga Pendidikan Muhammadiyah

Muhammadiyah sebagai harakah islamiyah dan da'wah salah satu perumus dasar pendidikan tentulah sangat mafhum terhadap perkembangan pendidikan Islam di Indonesia saat ini. dalam penetapan hukum baik berkaitan dengan umuruddin maupun murudunya di didalam Muhammadiyah pun mengalami metamorfosis yang cukup signifikan yang mengisyaraktkan bahwa upaya penggalian terhadap hukum Islam berusaha untuk menghubungkan teks dengan teks maupun teks dengan konteks sehingga berkesuaian dengan perkembangan zaman.

Lembaga pendidikan yang merupakan salah satu core da'wah di Muhammadiyah pun seharusnya sangat memahami bahwa di dalam Pembelajaran Al-Islam dan Kemuhammadiyahan perlu adanya pengembangan yang berkesuaian dengan beberapa keputusan dan perkembangan yang terjadi saat ini sehingga peserta didik mampu memahami, mengaplikasikan dan menganalisis permasalahan yang sangat kompleks sebagai akibat dari perkembangan dan arus globalisasi yang memiliki dua dampak yang kadang bertolak belakang.Pengenalan dan menanaman Aqidah dan Ibadah mahdhah dengan mengembalikan kepada teks aslinya sepertinya perlu diimbangi dengan masalah-masalah kontekstual yang berkembang pada saat ini, sehingga diharapkan peserta didik melek terhadap perkembangan zaman dan mampu menanggapi, merespon, memberikan alternative dan memformulasikan bahwa pendidikan Al-Islam dan Kemuhammadiyahan tidak hanya mencetak keshalihan pribadi saja melainkan mencetak keshalihan sosial.

Permasalahan yang terjadi saat ini, dengan model-model pemikiran Muhammadiyah yang begitu kaya, saat ini tidak diimbangi dengan konten materi pembelajaran Al-Islam yang 
dinamis. Konten materi yang disajikan masih cenderung mengikuti nalar normatif dengan mengesampingkan nalar historis dan pola dinanamisasi sebagai jawaban dari globalisasi yang massif di Indonesia. Tentu saja purifikasi dengan berpijak pada sumber hukum yang muttafaqun 'alaih dalam hal ibadah menjadi hal yang sangat urgen, akan tetapi yang menjadi perhatian saat ini adalah semangat purifikasi perlu diibangi dengan dinamisasi yang memberikan alternatif bagi kehidupan saat ini

Fakta yang terjadi saat ini adalah, tidak semua unsur siswa ataupun input saat ini secara pure merupakan kader Muhammadiyah ataupun warga Muhammmadiyah sehingga pembelajaran Al-Islam dan Kemuhammadiyah saat ini lebih banyak terfokus pada masalah-masalah formalisasi syari'ah dan menjurus ke doktrin dan sedikit menawarkan hal-hal yang berkaitan dengan pengembangan dan putusan-putusan resmi Muhammadiyah terbaru sehingga perlu adanya pengembangan. Permasalahan tersebut juga sangat berefek pada pensikapan peserta didik dalam menanggapi dan menghadapi perkembangan industrial dengan yang melahirkan masalahmasalah kompleks yang sekular, materialistik dan prakmatis.

Disisi lain materi yang diajarkan pada sekolah-sekolah Muhammadiyah dari tingkat dasar sampai dengan tingkat atas lebih banyak pada terfokus pada pengulangan materi tanpa banyak mengembangankan materi dengan mempertimbangkan beberapa kasus yang terjadi saat ini. Siswa juga lebih banyak menerima produk hukum tanpa banyak menerima konsep dan bagai mana hukum dikonstruk dengan menyandarkan pada sumbernya. Dengan permasalahan tersebut kita perlu kembali mengkaji kembali materi pelajaran yang disampaikan. 
Yazida Ichsan : Rekonstruksi Dan Pengembangan Materi Al-Islam di Lembaga Pendidikan Muhammadiyah

\section{B. MENGENALKAN ISTINBAT AHKAM MUHAMMADIYAH}

Pendidikan Agama Islam sebagi sebuah proses internalisasi dan kristalisasi nilai-nilai agama harus dipahami secara mengakar, dimana proses pengetahuan, keterampilan dan sikap harus didasarkan pada kesadaran akan ilmu pengetahuan yang telah dikonstruk Al-Qur'an dan Sunnah, bukan pada taqlid. Pengetahuan tersebut tidaklah mampu diperoleh tanpa mengetahui kaifiyah istinbat terhadap suatu hukum tertentu, sehingga perlu adanya pengenalan terhadap thariqatul istinbat ahkam sesuai dengan jenjang dan perkembangan kognitif yang dimiliki peserta didik.

Hukum sendiri didefinisikan sebagai Kalam Allah yang menyangkut perbuatan orang dewasa dan berakal sehat, bai bersifat imeratif, fakultatif atau menempatkan sesuatu sebagai sebab, syarat dan penghalang. 85 Para ulama' ushul dalam melakukan ijtihad menempuh beberapa jalan: Pertama, Istinbat dengan memahami nash yang jelas (qath'i). Kedua, Ijtihad, terhadap nash yang belum menunjukkan hukum satu masalah. Ketiga, Ijtihad yang di dalam memahami masalah yang hanya ditunjuki oleh jiwa nash, yakni kemaslahatan. Perlu dipahami di dalam Muhammadiyah pun memiliki kerangka metodologis di dalam pengambilan hukum, yaitu :

1. Dalam memutuskan suatu keputusan, dilakukan dengan cara musyawarah. Dalam menetapkan masalah ijtihad, digunakan sistem ijtihad jama'iy. Dengan demikian pendapat perorangan dari anggota majelis, tidak dapat dipandang kuat. 
2. Di dalam beristidlal, dasar utamanya adalah Al-Qur'an dan Sunnah Shahihah. Ijtihad dan istinbath atas dasar illah ${ }^{86}$ terhadap hal yang tidak terdapat di dalam nash dapat dilakukan. Sepanjang tidak menyangkut bidang ta'abudi, 87 dan memang merupakan hal yang diajarkan dalam memenuhi kebutuhan hidup manusia. Dengan perkataan lain Majelis Tarjih menerima ijtihad, termasuk qiyas sebagai cara dalam menetapkan hukum yang tidak ada nashnya secara langsung. 88

3. Tidak mengikatkan diri pada suatu madzhab, 89 tetapi pendapat-pendapat mazhab, dapat menjadi pertimbangan

86 Jumhur Ulama' mendefnisikan ilat dengan sifat, ciri, alasan, motif atau sebab lahir yang dapat diukur, baik bentuk, individu, waktu maupun keadaan yang menetapkan dan sesuai dengan hukum. Departemen Pendidikan Nasional Pusat Pembukuan Bagian Proyek Pengembangan Sistem dan Pembukuan Dasar, Suplemen Ensiklopedi Islam ( Jakarta: PT Ichtiar Baru Van Hoeve, 2003), hlm 235

87 Lihat Manhaj Tarjih Muhammadiyah

88 Pertama Ijtihad bayani, yaitu usaha penggalian hukum dari nash dzanni dengan mencari dasar-dasar interpretasi atau tafsir. Bayan sendiri terpilah menjadi beberapa macam, yaitu bayan taqrir, bayan tafsir, bayan tagyir, bayan tabdil, dan bayan dharurat. Bayan taqrir adalah penjelasan dalam rangka mengungkapkan suatu makna dengan dasar-dasar lain, yang membuat sesuatu lebih jelas, baik makna kata-kata maupun ungkapan dalam nash maupun dalil. Bayan tafsir adalah penjelasan suatu lafal atau kata-kata, sehingga maksud nash tersebut menjadi lebih jelas. Bayan taghyir adalah keteranganketerangan yang mengubah dari makna lahir menjadi makna yang dituju, seperti kata-kata yang mengandung pengecualian atau istisna'. Adapun bayan tabdil adalah upaya mencari penjelasan dengan jalan nash. Bayan dharuri adalah keteragan yang tidak disebutkan, tetapi harus diungkapkan.Kedua ijtihad qiyasi, yaitu upaya yang sungguh-sungguh untuk memberikan solusi hukum bagi suatu masalah yang tidak ada ketentuan nashnya berdasarkan kesamaan 'Tlat.Ketiga, ijtihad Istislahi, yaitu mencari solusi hukum bagi suatu masalah yang tidak ditemukan ketentuan hukumnya dalam nash Al-Qur'an atau pun Hadist, dengan mendasarkan pada kemaslahatan yang akan dicapai. Implementasi ini bisa ditempuh dengan beberapa metode, yaitu : metode istihsan, metode sad al dzari'ah, metode istislahi dan metode 'urf.

89 Secara bahasa madzhab diartikan tempat pergi, rujukan atau sandaran dalam mengamalkan ibadah. Madzhab juga diartikan sebagai aliran, golongan dan sekte. 89 Abbudin Nata, Studi Islam Komprehensif (Jakarta: Kencana Prenada Media Group.2011) hlm 534. Menurut ahli fiqh, madzhab didefinisikan sebagai aliran atau jalan yang ditempuh dalam pengamalan hukum yang dipercayainya. Tim Majelis Tarjih dan Tajdid PP Muhammadiyah, 
Yazida Ichsan : Rekonstruksi Dan Pengembangan Materi Al-Islam di Lembaga Pendidikan Muhammadiyah

dalam menetapkan hukum. Sepanjang sesuai dengan jiwa AlQur'an dan As-Sunnah atau dasar-dasar lain yang dipandang kuat.

Bagi Muhammadiyah, ijtihad mesti diakukan dalam upaya menggali ketentuan-ketentuan hukum yang ada secara langsung dari Al-Qur'an maupun hadist. Ini mesti dilakukan agar keberagamaan umat Islam sesuai dengan sumber aslinya, tidak ada sedikit pun, baik berupa penambahan ataupun pengurangan. Kesesuaian ini hanya akan ada jika ijtihad dilakukan secara langsung, tidak melalui pintu-pintu madzhab . dengan sendirinya, hal ini memunculkan gagasan untuk tidak bermadzhab. ${ }^{90}$

Berprinsip terbuka dan toleran, dan tidak beranggapan bahwa hanya Majelis Tarjih yang paling benar. Keputusan diambil atas dasar landasan dalil-dalil yang dipandang paling kuat, yang didapat ketika keputusan diambil. Dan koreksi dari siapa pun akan diterima. Sepanjang dapat diberikan dalil-dalil lain yang lebih kuat. Dengan demikian, Majelis Tarjih dimungkinkan mengubah keputusan yang telah ditetapkan.

4. Di dalam masalah aqidah (tauhid), hanya digunakan dalildalil yang mutawatir.

5. Tidak menolak ijma' sahabat, sebagai dasar suatu keputusan.

6. Terhadap dalil-dali yang tampak mengandung ta'arudl, digunakan cara : Al-Jam'u wat Taufiq. Dan kalau tidak dapat baru dilakukan Tarjih.

Fatwa-fatwa Tarjih: Tanya Jawab Agama 2 (Yogyakarta: Suara Muhammadiyah cet ke-8) hlm 212.

90 Ibid, hlm 85-86 
7. Menggunakan asas "Sadd-u Daraai' untuk menghindari terjadinya fitnah dan mafsadah. 91

8. Menta'lil dapat digunakan untuk memahami kandungan dalil-dalil Al-Qur'an dan As-Sunnah, sepanjang sesuai tujuan syari'ah. Adapun qaidah: “Al-Hukmu yaduru ma'a illatihi wujuudn wa 'adaman dalam hal-hal tertentu dapat berlaku. 92

9. Penggunaan dalil-dalil untuk menetapkan suatu hukum, dilakukan dengan cara komprehensif, utuh dan bulat, tidak terpisah.

10. Dalil-dalil umum Al-Qur'an dapat ditakhsis dengan hadist Ahad, kecuali dalam bidang Aqidah.

11. Dalam mengamalkan agama Islam, menggunakan prinsip “AtTaisir".

12. Dalam bidang ibadah yang diperoleh ketentuan-ketentuannya dari Al-Qur'an dan As-Sunnah, pemahamannya dapat dengan menggunakan akal, sepanjang diketahui latar belakang dan tujuannya. Meskipun harus diakui, bahwa akal bersifat nisbi, sehingga prinsip mendahulukan nash daripada akal memiliki kelenturan dalam menghadapi perubahan situasi dan kondisi.

13. Dalam hal-hal yang termasuk al-Umuru dunyawiyah yang tidak termasuk tugas tugas para nabi, penggunaan akal sangat diperlukan, demi kemaslahatan umat.

14. Untuk memahami nash yang mustarak, faham sahabat dapat diterima.

91 Tujuan digunakan saddu zarii'ah pada dasarnya untuk menghindari fitnah dan mafsadah dengan tujuan digunakan untuk kemaslahatan manusia.

92 Salah satu dari model ijtihad terhadap nash adalah dengan meneliti sebab ('illat) hukum yang melatarbelakangi ketentua hukum. 
Yazida Ichsan : Rekonstruksi Dan Pengembangan Materi Al-Islam di Lembaga Pendidikan Muhammadiyah

15. Dalam memahami nash, maka dhahir didahulukan dari ta'wil dalam bidang aqidah. Dan ta'wil sahabat dalam hal itu, tidak harus diterima. 93

Selama ini materi pembelajaran Al-Islam tidak begitu banyak mengenalkan metodologi istinbat ahkam yang menghasilkan produk hukum, sehingga peserta didik memiliki kemungkinan lebih terfokus kepada produk hukum, sehingga perlu diperkenalkan perspektif dan metodologi istimbat ahkam yang digunakan di dalam Muhammadiyah. Disisi lain, didalam Muhammadiyah sendiri memiliki keunikan dalam produk hukum yang terdiri dari: Putusan resmi Muhammadiyah, fatwa dan wacana sehingga peserta didik perlu mengetahui mana yang termasuk bagian putusan, fatwa dan wacana. ${ }^{94}$

Pengetahuan dan pemahaman terhadap produk tarjih tersebut diharapkan mampu memberikan perspektif yang luas, bahwa perkembangan yang ada di dalam Muhammadiyah sendiri bukanlah suatu doktrin saja melainkan sebuah upaya penggalian hukum didasarkan pada kajian yang komprehensif, ilmiah dan didsarkan pada ijtihad jama'iy yang bukan hanya melibatkan ulama yang berkompeten dalam bidangnya melaikan juga melibatkatkan tenaga ahli dalam bidang tertentu (dalam aspek dinamisasi). Ijtihad sebagai metodologi pengambilan hukum memberikan keleluasaan bahwa pengkajian terhadap sumber hukum selalu berkembang dan mampu memberikan alternative bagi perkembangan zaman.

Berkembangannya putusan, fatwa dan wacana diharapkan bahwa peserta memiliki nilai toleransi terhadap

93 Asjmuni Abdurrahman,.Manhaj Tarjih Muhammadiyah Metodologi dan Aplikasi,Yogyakarta: Pustaka Pelajar. 2012),h lm 12-14

94 TIM PP Muhammadiyah Majelis Tarjih, Tanya Jawab agama 5, (Yogyakarta : Suara Muhammadiyah 2007 cet 2), hlm. 11-12. 
putusan hukum yang dimiliki organisisai lain dan tidak serta memandang bahwa segala putusan yang dimiliki Muhammadiyah selalu benar, melainkan Muhammadiyah memiliki keterbukaan terhadap masukan, kritik maupun koreksi. Disisi lain, peserta didik mampu mendeskripsikan bagaimana pola-pola hukum yang digunakan Muhammadiyah dengan beberapa perangkat yang digunakan.

\section{HARMONISASI NORMATIFITAS DAN HISTORISITAS}

Corak purifikasi dan dinamisasi yang bersifat tengahan yang diyakini Muhammadiyah, sepertinya perlu dikembangkan di dalam pembelajaran baik konten, maupun praktik di dalam pembelajaran. Karakteristik hukum Islam: akhlaki, Insani, wasati dan harakah perlu dipadukan dengan perkembangan era industrial yang melahirkan permasalahan-permasalahan yang kompleks di dalam masyarakat maupun dunia pendidikan sehingga seorang siswa tidak "kaget" bahkan "tenggelam" dengan beberapa kenyataan yang sangat bertolak belakang normatifitas.

Integralisasi ilmu qauliyyah, kauniyyah dan nafsiyyah (humaniora) menjadi hal yang tidak dapat dilepaskan dan saling menguatkan. Pelajaran fiqih/ibadah misalnya selain ditekankan pada aspek purifikasi (mahdhah) sekiranya perlu disajikan pula aspek dinamisasi pada aspek pengembangan ibadah mahdah terhadap pemberdayaan pribadi ataupun sosial. Wudhu' tidak hanya dikaitkan dengan kaifiyat yang berkesuaian dengan tuntunan ibadah sesuai dengan putusan Muhammadiyah, melainkan dengan beberapa perspektif; kesehatan, eksistensi air, ekonomi dan psikologis. Aspek ibadah yang tetap 
Yazida Ichsan : Rekonstruksi Dan Pengembangan Materi Al-Islam di Lembaga Pendidikan Muhammadiyah

seharusnya berdampak pada masalah mua'amalah yang berdasarkan pada nilai-nilai tauhid.

Menurut kuntowijoyo, saat ini umat Islam terjebak dalam mistis kenyataan.

Penyajiam materi Aqidah-Akhlak yang saat ini lebih banyak menekankan pada aspek normative, dass solen, konsep, perlu pula disajikan kasus-kasus tertentu yang saat ini dihadapi siswa terutama untuk materi pembelajaran di Tingkat SMA. Deskripsi syirik, tauhid, akhlak, moral dan lain sebagainya perlu diperluas dengan melihat perkembangan era globalisai yang berdampak pada perubahan pada individu maupun sosial baik dalam cara perspektif berfikir, tingkah laku maupun nilai-nilai dalam masyarakat. Pergeseran nilai yang terjadi di masyarakat industrial perlu dianalisis di kritisi dan ditemukan adakah alternatif-aplikatif terhadap beberapa permasalahan yang terjadi.

Pengembangan materi pembelajaran Al-Islam dan Kemuhammadiyahan perlu melibatkan banyak pihak dalam penyusunannya, bukan hanya pada seseorang yang ahli dalam bidang agama saja, melainkan melibatkan psikolog, sosiolog, ilmuan, motivator, ekonom, pembisnis, dokter maupun tenaga ahli lainnya sehingga ada penguatan, integrasi dan interkoneksi antara nilai ajaran suatu agama dengan kenyataan yang ada dan terjadi sehingga siswa bukan hanya paham dalam masalah agama akan tetapi mampu menjawab permasalah yang terjadi dengan sudut pandang agama.

\section{DINAMISASI DAN INTERNALISASI NILAI}

Secara normatif, Ideologi Muhammadiyah yang reformismodernis (pembaruan) lebih menampilkan corak Islam yang 
berkemajuan, yang memadukan antara pemurnian (purifikasi) dan pengembangan (dinamisasi) dan bersifat tengahan (wasithiyyah) di dalam meyakini, memahami dan melaksanakan ajaran Islam, sehingga Islam senantiasa aktual dan menjadi agama untuk peradaban (din al-hadharah) sepanjang zaman. 95 Konsep ideologi yang sedimikian baiknya perlu dikembangkan pada akar rumput dan dalam dunia pendidikan sehingga dalam kondisi tertentu siswa mampu mengaplikasikan pola analisis dengan memberikan alternatif.

Pengembangan tema dan materi yang disampaikan kepada peserta didik sepertinya perlu adanya dinamisasi. Semanggat purifikasi dan internalisasi nilai dasar dan pengetahuan dasar terhadap materi tertentu menjadi hal yang sangat mutlak harus dikuasasi pesertadidik. Dalil-dalil yang melatarbelakangi munculnya suatu hukum tertentu juga menjadi hal yang perlu dikuasai, sehingga pesertadidik mampu berittiba' dan mengetahui secara pasti lahirnya suatu hukum. Disisi lain, kontektualisasi terhadap permasalahanpermasalahan yang timbul perlu dikaji dengan kerangka yang dibangun Majelis Tarjih. Kiranya tema dan materi tersebut perlu mempertimbangkan perkembangngan kognitif dan psikologi peserta didik. Adapun beberapa contoh dinamisasi adalah sebagai berikut : 
Yazida Ichsan : Rekonstruksi Dan Pengembangan Materi Al-Islam di Lembaga Pendidikan Muhammadiyah

Tabel 1. Contoh Dinamisasi Pengembangan Materi Pembelajaran

\begin{tabular}{|c|c|c|}
\hline No & $\begin{array}{c}\text { Standar } \\
\text { Kompetensi }\end{array}$ & Dinamisasi \\
\hline 1 & $\begin{array}{l}\text { Melaksanakan } \\
\text { Thaharah }\end{array}$ & $\begin{array}{l}\text { - Fiqih air sebagai upaya memelihara } \\
\text { eksistensi air, redefinisi air untuk } \\
\text { bersuci: limbah, dll } \\
\text { - Kesehatan dalam pandangan } \\
\text { normative dan historis }\end{array}$ \\
\hline 2 & $\begin{array}{l}\text { Memahami } \\
\text { pernikahan } \\
\text { (munakahat), } \\
\text { talak dan ruju' }\end{array}$ & 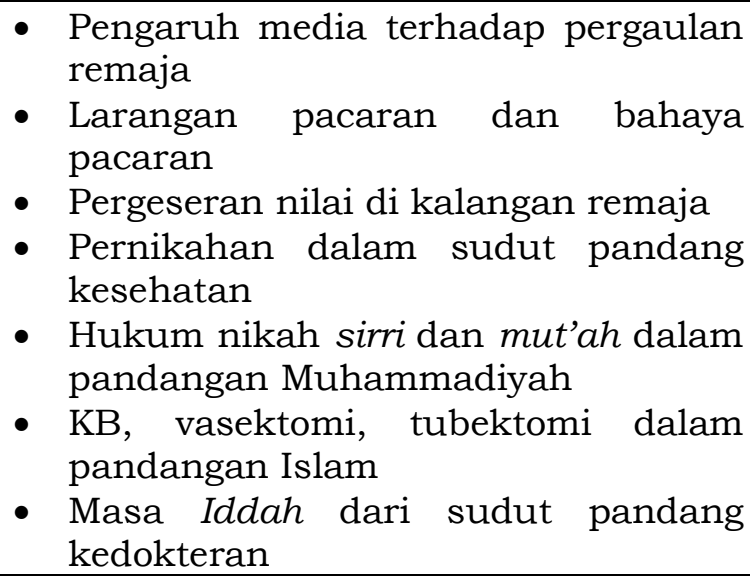 \\
\hline 3 & $\begin{array}{l}\text { Memahami } \\
\text { makanan } \\
\text { minuman }\end{array}$ & $\begin{array}{l}\text { - Memahami junk food, makanan- } \\
\text { makanan yang mengandung } \\
\text { pengawet dan efek makanan } \\
\text { terhadap kesehatan } \\
\text { - Makanan halal dan haram ditinjau } \\
\text { dari kacamata kesehatan } \\
\text { - Obat-obatan yang mengandung } \\
\text { bahan-bahan haram } \\
\text { - Jamu sebagai kerifan lokal } \\
\text { - Media masa dan makanan } \\
\text { - Medsos dan makanan } \\
\text { Menjamurnya tempat makan }\end{array}$ \\
\hline
\end{tabular}

Masalah thaharah misalnya, perlu adanya pengembangan berkaitan dengan fiqh air, regulasi berkaitan dengan air, eksistensi dan perspektif kedokteran sehingga thaharah tidak hanya dipandang sebagai metode untuk bersuci dari najis saja melainkan dapat dilihat dari segi kesehatan, 
pemberdayaan lingkungan dan pemberdayaan masyarakat dalam hal makanan dan minuman misalnya pendekatan pendekatan normatif sebagai sebuah konsep, adab dan tata aturan perlu dikembangkan kembali pada permasalahan “jajanan kekinian", pengawet, pewarna,pupuk pertisida, kekuatan ekonomi, gaya hidup sehat, makanan yang halal dan thayyib sehingga peserta didik mampu mengkonstruksi mengkontektualisasikan dan membumikan "isyarat normatif teks".

Tema-tema yang berkaian dengan masalah media sosial, pubertas, pacaran, pernikahan dan berkaitan dengan masalah $\mathrm{KB}$, vasektomi, tubektomi, penyakit sex menular, nikah muda, thalaq dalam perspektif Muhammadiyah, masa iddah dalam perspektif kedokteran menjadi hal yang perlu dibahas sehingga seorang siswa tentunya sangat mafhum terhadap nilai dasar agama dan mampu menhadapi dan memahami esensi dasar ajaran agama terhadap permasalahan yang menimpa. Tentunya masih banyak lagi tema yang perlu dikembangkan sehingga minimal mengetahuhi istinbat hukum dalam Muhammadiyah dan mengetahui arus dinamisasi sebagai sebuah kenyataan.

Tentunya hal yang sedemikian itu harus melihat mekanisme psikologi kehidupan beragama pada masa kanakkanak sampai dewasa dengan mempertimbangkan jenjang pendidikan yang ada. Masa kanak-kanak yang sangat menonjol adalah mekanisme imitasi yang berkembang lewat proses peniruan didorong rasa ingin tahu curoisity pada masa ini pengenalan terhadap hukum terpusat pada pendidik dan lebih banyak pada pembiasaan, dan praktik. Sebagian remaja mengalami pengalaman batin lebih intensif dan mendalam, Pada masa ramaja mengalami konflik keraguan beragama sementara 
Yazida Ichsan : Rekonstruksi Dan Pengembangan Materi Al-Islam di Lembaga Pendidikan Muhammadiyah

yang lain bersikap hipokrit bahkan sebagian yang lain tidak peduli dengan agama. adanya faktor keragu-raguan (religious doubt and conflict). 96 Dengan paradigma tersebut, tentunya konten akan disesuaikan dengan perkembangan kognitif, maupun afeksi sebagai akibat dari pengalaman pribadi yang dipengaruhi oleh keluarga, lingkungan maupun sosial.

\section{E. PENDIDIKAN YANG BERKEMAJUAN}

Perkembangan dunia industri dan teknologi yang berkembang secara masif sangat berdampak pada lingkungan pendidikan. Di satu sisi, lembaga pendidikan belum siap untuk memaksimalkan perkembangan teknologi, disisi lain lembaga pendidikan dituntut untuk menginternalisasikan nilai terhadap peserta ddik yang saat ini lebih banyak berkecimpung dalam dunia maya. Kiranya pendidikan yang berkemajuan di lembaga pendidikan Muhammadiyah perlu mengkloning, semangat purifikasi dan dinamisasi di dalam Muhammadiyah. Purifikasi ditafsirkan dengan penanaman kembali nilai-nilai kebudayaan dan kearifan yang dimiliki masyarakat sekitar (urf shalih), unggah ungguh, semangat gotong royong, toleransi dan empati. Dinamisasi diartikan sebagai sebuah paradigma dan proses berfikir diluar kotak dan trasendent sehingga peserta didik bukan hanya sebagai konsumen di dalam menerapkan teknologi melainkan mampu menggunakannya untuk menunjang kehidupan.

Kiranya perlu adanya pengembangan berkaitan dengan konten, strategi maupun penyajian bahan ajar, sehingga peserta didik secara teks sangat menguasai subtansi dari ajaran Islam

96 M.A. Subandi, Psikologi Agama dan Kesehatan Mental, (Yogyakarta; Pustaka Pelajar.2013), hlm 41-54 
dengan mendasarkan pada sumber hukum dasar, secara konteks sangat memahami dan mampu menggambil sikap, maupun menganalis setiap pebelajaran yang didapatkan serta mampu dan sadar bahwa saat ini umat Islam mampu mengaktualisasikan nilai ibadah dalam setiap perikehidupan peserta didik.

Pendekatan teks, konteks dan pengalaman spiritual yang dihadapi peserta didik pun harus menjadi hal yang diperhitungkan di dalam pembelajaran. Penggalian dan pengkajian terhadap ayat-ayat ilmu pengetahuan di dalam AlQur'an pun perlu dikaji kembali, sehingga, disatu sisi pemurnian aqidah dan ibadah berjalan dengan maksimal, disisi lain, peserta didik mampu menemukan ilmu-ilmu baru. Dalam diri peserta didik diberikan stimulan bahwa perlu adanya nalar kritis dan realistis dalam setiap materi pembelajaran yang disampaikan.

Konten pelajaran yang disajikan juga harus mampu memberikan sebuah terobosan dimana peserta didik bukan hanya cerdas secara konitif akan tetapi memiliki sebuah nilai sehingga mampu memberikan sebuah alternative di dalam sikap, tindakan maupun cara pandang yang berbeda untuk merealisasikan posisi manusia secara holistic sebagai seorang hamba, makhluk sosial, dan sebagai khalifah di muka bumi ini.

\section{F. KESIMPULAN}

Rekonstruksi dan pengembangan materi baru yang lebih aktual, aplikatif dan lebih membumi kiranya perlu digalakan kembali dengan menyadarkan bahwa materi pembelajaran AlIslam saat ini harus mampu membumikan nalar normative dan historis di dalam pendidikan, materi bukan hanya kerangka 
Yazida Ichsan : Rekonstruksi Dan Pengembangan Materi Al-Islam di Lembaga Pendidikan Muhammadiyah

konsep saja melainkan juga menyajikan permasalahan aktual yang berkembang disetiap masa.Tidak dapat dipungkiri bahwa salah satu subtansi ajaran Islam adalah dokrin, akan tetapi doktrin sebagai sebuah ajaran harus mampu menyelesaikan permasalahan dan menjadi alternative di dalam masyarakat.

Materi Al-Islam juga harus mampu memberikan wawasan dasar istinbat hukum sehingga baik pendidik maupun pesertadidik tidak terjebak taqlid yang kemudian menimbulkan ta'ashub (fanatisme yang berlebihan). Dengan pengetahuan keilmuan yang mewadahi pesertadidik memiliki sikap toleran, tawasuth dan berkemajuan peserta didik dapat memahami bahwa risalah islam adalah sebuah alternatif dan formula bagi kehidupan manusia. Materi juga harus berkolaborasi dengan paradigm keilmuan lain, seperti ilmu alam, kedokteran, sosiologi, antropologi, budaya, psikologi maupun ilmu lainnya sehingga materi yang didapatkan peserta didik menjadi materi yang holistik dimana siswa bukan hanya memahami konsep normatif saja melainkan dapat mengaplikasikan beberapa ilmu dengan merujuk pada ilmu agama dan memiliki nalar ilmiah.

Pengembangan materi pembelajaran juga harus memperhatikan pada pola perkembangan anak, sehingga konten yang disajikan berkesesuaian dengan tingkat perkembangan kognisi, afeksi dan psikomotor sehingga materi yang dikembangkan pada setiap jenjang akan berkesinambungan. 


\section{DAFTAR PUSTAKA}

Abdurrahman Asjmuni .2012. Manhaj Tarjih Muhammadiyah Metodologi dan Aplikasi,Yogyakarta: Pustaka Pelajar

Departemen Pendidikan Nasional Pusat Pembukuan Bagian Proyek Pengembangan Sistem dan Pembukuan Dasar.2003.Suplemen Ensiklopedi Islam.Jakarta: PT Ichtiar Baru Van Hoeve.

Kuntowijoyo. Islam Sebagai Imu. 2006.Yogyakarta: Tiara Wacana.

M.Toyibi dkk.2003. Muhammadiyah dan Budaya Lokal : Dialektika Muhammadiyah dan Seni Lokal ,Surakarta: UMS press

M.A. Subandi.2013. Psikologi Agama dan Kesehatan Mental.Yogyakarta; Pustaka Pelajar.

Mulkhan, Abdul Munir. 2013. Ajaran dan Pemikiran K.H. Ahmad Dahlan. Yogyakarta : Galangpress.

Rachmat Syafe'i.2015. Ilmu Ushul Fiqh. Bandung: Pustaka Setia.

Suryanegara, Ahmad Mansur. 2012. Api Sejarah : Mahakarya Perjuangan Ulama dan Santri dalam Menegakkan Negara Kesatuan Republik Indonesia, Yogyakarta : PT Grafindo Media Pratama,

Syarif Hidayatullah. 2004. Muhammadiyah dan pluralitas agama di Indonesia,Yogyakarta : Pustaka Pelajar.

Tim Majelis Tarjih dan Tajdid PP Muhammadiyah. 2003. Fatwafatwa Tarjih: Tanya Jawab Agama 2.Yogyakarta: Suara Muhammadiyah cet ke-8.

Tim Majelis Tarjih dan Tajdid PP Muhammadiyah. 2007. Tanya Jawab agama 5. Yogyakarta : Suara Muhammadiyah cet 2. 